\title{
В. В. НовИКОВ
}

\section{АБХАЗИЯ - 2019: ОТ ХАДЖИМБА ДО ХАДЖИМБА}

\author{
Владимир Владимирович Новиков, канд. ист. наук, ст. науч. сотр. \\ Института социальных и политических исследований \\ Черноморско-Каспийского региона. \\ E-mail: novik222@mail.ru
}

\begin{abstract}
Аннотация. Рассматриваются ход и результаты предвыборной президентской кампании в Абхазии в 2019 г., а также факторы, определившие ее характер (болезнь Аслана Бжания, связанный с этим перенос выборов, количество кандиАатов и $л$.). Показана расстановка си^ накануне начала кампании. Аана характеристика основных кандидатов в президенты и сил, которые вы вигали этих кандилатов. Зафиксирован полицентризм абхазской политики, в которой сосуществуют не только в^асть, оппозиция и «третья сила», но и электоральные конкуренты как власти, так и оппозиции, а также многочисленные претенденты на роль «третьей силы», что и привело к распылению электората на президентских выборах. Рассмотрен ход президентской кампании, причем акцент слелан на анализе программных установок кандидатов и их политического стиля. Прослежены политические маневры власти, оппозиции и команды Александра Анкваба межлу двумя турами. Особое внимание уделяется причинам, позволившим Раулю Хаджимбе выиграть президентские выборы. Рассмотрена ситуация после президентских выборов, Аан прогноз возможного развития событий.

Ключевые слова: Абхазия, Рауль Хаєжимба, Аслан Бжания, А^хас Квициниа, Олег Аршба, Сергей Шамба, Александр Анкваб.
\end{abstract}

Президентская кампания 2019 г. стала событием, которого и власть, и оппозиция ждали пять лет.

Оппозиция была уверена, что приход к власти Рауля Хаджимба в результате событий 27 мая 2014 г. не был легитимным. В течение первого президентского срока Хаджимбы несколько раз выдвигался лозунг его досрочной отставки. Соответственно, выборы 2019 г. рассматривались как своего рода генеральное сражение после поражения в 2014 г. Именно это и определило характер кампании.

\section{ВbІБОРЫ-2019: ОСОБЕННОСТИ КАМПАНИИ}

При всем внешнем спокойствии кампании 2019 г. ее характер определился рядом особенностей, которые отличают ее от всех предыдущих. Во-первых, она началась с болезни основного оппонента власти Аслана Бжания, и, вне зависимости от происхождения этой болезни, она стала политическим фактором. Во-вторых, болезнь повлекла за собой изменение правил игры - перенос сроков. В-третьих, самое большое количество кандидатов за всю историю президентских выборов - 9. В-четвертых, впервые имел место второй тур. В-пятых, первый тур зафиксировал наличие не двух, а трех лидеров, которые пришли к промежуточному финишу с минимальным отрывом друг от друга.

\section{«АЕЙСТВУЮЩИЕ АИЦА»: \\ ОСНОВНЫЕ АКТОРЫ АБХАЗСКОЙ ПОАИТИЧЕСКОЙ СЦЕНЫ И КАНАИААТЫ В ПРЕЗИАЕНТЫ}

Политическая борьба в период первой президентской каденции Рауля Хаджимбы была борьбой «двух с половиной сил» - власти, оппозиции и постоянно возникающих претендентов на роль «третьей силы» (партия «Айнар» и др.). Однако количество кандидатов на выборах 2019 г. 
показало, что картина намного сложнее и речь надо вести не о «третьей силе», а о многочисленных «третьих силах». Более того, провластный и оппозиционный лагеря пришли к выборам после многочисленных трансформаций.

Итак, власть выдвинула действующего президента Рауля Хаджимбу в паре с главой аналитического управления АП РА Асланом Барцицем. При этом к моменту первого назначения даты выборов в апреле 2019 г. Хаджимба подошел с высоким антирейтингом и в ситуации очень серьезной потери элитной базы поддержки.

Напомним, что он победил в 2014 г. как кандидат от широкой коалиции, которая включала в себя очень разных политиков - от Артура Миквабия и Беслана Бутбы до Сергея Шамбы и Шамиля Адзынбы, а также лидеров некоторых национальных общин (в первую очередь армянской). Однако к началу 2017 г. эта коалиция фактически распалась [2]. В результате событий 2017-2018 гг. часть бывших участников этой коалиции (например, Сергей Шамба) перешли в оппозицию [3].

Однако на грани 2017-2018 гг. обозначился еще один значимый раскол: Хаджимба стал терять и часть тех сил, которые сопровождали его политическую карьеру с самого начала. В первую очередь речь идет о группе влиятельных политиков во главе с Дмитрием Ардзинбой и Ильей Гуния. Этот раскол оформился через конфликт вокруг правительства Беслана Барцица, отставку вице-президента Виталия Габния, фактический отказ провластной ветеранской партии «Аруаа» поддержать Хаджимба [3].

Более того, этот раскол внутри власти привел к тому, что часть ранее поддерживавших Хаджимбу сил пыталась выдвинуть своего рода «провластную альтернативу» главе государства в лице экс-главы СГБ, бывшего секретаря Совета безопасности и первого вице-премьера Астамура Тарбы. Разговоры об этом стали ходить после отставки Габния [4]. В результате $A c m a м y p$ Тарба первым заявил о своих президентских амбициях в марте 2019 г. и выдвинулся в паре с известным юристом и общественным деятелем Тамазом Кецбой.

Оппозиция к весне 2019 г. имела своим безусловным лидером депутата парламента, главу фонда АПРА Аслана Бжания. Она была оформлена в «зонтичную» организацию - Союз политических и общественных организаций РА, в ядре которой были три силы - ветеранская партия «Амцахара» во главе с Алхасом Квициниа, партия «Единая Абхазия» во главе с Сергеем Шамбой и группа молодых политиков во главе с Теймуразом Хишбой, объединившиеся в Общенациональное движение по защите государственности (ОНД). К ним же примкнули некоторые другие общественные организации - «Абзанхара» Нугзара Ашубы, «Кьяраза» Дмитрия Дбара и т. д. [3]. Этот альянс сумел сформировать также депутатскую группу в парламенте, в которую вошли как опытные (Батал Табагуа), так и молодые (Батал Айба, Лаша Ашуба, Астамур Аршба) политики.

Однако в середине апреля 2019 г. тяжелое заболевание Аслана Бжания привело к тому, что оппозиция рисковала остаться без кандидата и оказалась перед альтернативой: либо надеяться на врачей и ждать Бжания, либо срочно искать дублера. В результате известных событий 2021 мая оппозиция сумела выиграть время, добившись переноса выборов.

Примерно до конца первой декады июля тактика оппозиции заключалась в том, чтобы дожидаться восстановления Бжания. 1 июля «Единая Абхазия» зарегистрировалась в ЦИК для выдвижения ${ }^{1}$ кандидата в президенты ${ }^{2} .5$ июля в ЦИК зарегистрировалась и инициативная группа граждан по выдвижению Аслана Бжания кандидатом³.

10 июля на съезде партии «Амцахара» кандидатом в президенты был выдвинут ее глава Алхас Квициниа. Кандидатом в вице-президенты стал Дмитрий Дбар. 14 июля Бжания передал через соратников заявление об отказе баллотироваться в президенты, так как сроки его медицинской реабилитации могут затянуться .

\footnotetext{
${ }^{1}$ Отметим, что по абхазскому законодательству кандидат в президенты может быть выдвинут либо инициативной группой, либо партией. В случае выдвижения партией кандидат не обязан собирать подписи граждан. Судя по всему, регистрация «Единой Абхазии» была нужна, чтобы создать механизм для быстрой регистрации Бжания.

2 «Единая Абхазия» зарегистрировалась в ЦИК // Нужная газета. - 2019. - 2 июля. - URL: https://abh-n.ru/edinayaabxaziya-zaregistrirovalas-v-cik/

${ }^{3}$ ЦИК зарегистрировал группу по выдвижению в президенты Аслана Бжания // Спутник-Абхазия. - 2019. - 5 июля. - URL: https://sputnik-abkhazia.ru/politics/20190705/1027836235/TsIK-zaregistriroval-gruppu-po-vydvizheniyu-v-prezidentyAslana-Bzhaniya-.html

${ }^{4}$ Аслан Бжания не будет баллотироваться на президентских выборах в Абхазии // Спутник-Абхазия. - 2019. - 14 июля.

URL: https://sputnik-abkhazia.ru/Abkhazia/20190714/1027914518/Aslan-Bzhaniya-ne-budet-uchastvovat-v-prezidentskikhvyborakh-v-Abkhazii.html
} 
Однако еще 10 июля на съезде «Амцахары» стало очевидно, что решение о смене оппозиционного кандидата принято. Во-первых, участникам съезда было зачитано обращение Бжания с пожеланиями удачной работы ${ }^{5}$. Во-вторых, в работе съезда приняли участие сторонники Бжания (члены инициативной группы, Сергей Шамба и другие), которые никак не высказали свой протест против выдвижения Квициниа. В-третьих, сам Квициниа позиционировал свое выдвижение как фактически вынужденную меру из-за болезни Бжания 6 . Таким образом, следует признать, что болезнь Аслана Бжания не привела к расколу оппозиционного блока.

Однако оппозиция столкнулась с той же проблемой, что и власть - наличием конкурента внутри своей электоральной ниши. Если для власти таким конкурентом стал Астамур Тарба, то для оппозиции им оказался советник министра обороны РА генерал Олег Аршба, выдвинувшийся в паре с торговым представителем Абхазии в РФ Олегом Барцицем. В предвыборной кампании этой пары самое активное участие принял экс-президент, депутат парламента Александр Анкваб. При этом главой предвыборного штаба тандема Аршба - Барциц стал ближайший соратник Анкваба, премьер-министр в 2011-2014 гг. Леонид Лакербая.

Противоречия между Александром Анквабом и оппозицией были публично обозначены летом - осенью 2017 г., когда экс-президент в серии своих публичных выступлений начал позиционировать себя как и не оппозиционный, и не как провластный политик. Тогда же появились слухи, что Анкваб может стать главой предвыборного штаба Рауля Хаджимбы (впоследствии они не подтвердились) [2]. В 2018 г. Анкваб воздерживался от поддержки Бжания, что вызывало вопросы у некоторых сторонников оппозиции [3]. Таким образом, перед президентскими выборами 2019 г. пути оппозиционного блока и Александра Анкваба разошлись.

Еще одним кандидатом в президенты стал бывший лидер партии «Айнар» Алмас Джапуа, которого выдвинуло движение «Общее дело». Это движение стало очередной попыткой оформить «третью силу», которая могла бы оппонировать как власти, так и оппозиции. Напомним, что в самом начале президентской кампании много говорилось, что кандидатом от «Общего дела» станет глава Священной Митрополии Абхазии отец Дорофей (Дбар). Однако последний публично отказался от участия в президентских выборах [3]. Важно при этом отметить, что президентская кампания, слухи о возможном участии отца Дорофея и его отказ совпали с очередным обострением церковного кризиса в республике [1].

Отдельно следует выделить группу кандидатов, которые также пытались претендовать на роль «третьей силы»: бывший глава МВД, советник президента РА Леонид Дзапшба (Вианор Ашба - кандидат в вице-президенты); бывший первый вице-премьер, бывший и. о. премьера Шамиль Адзынба (Рафаель Ампар - кандидат в вице-президенты); писатель, общественный деятель Астамур Какалия (Астамур Айба - кандидат в вице-президенты); бывший гендиректор РУП «Абхазчай» Астамур Отырба (Давид Дасания - кандидат в вице-президенты) ${ }^{7}$; бывший директор школы милиции, преподаватель АГУ Артур Анкваб (Сослан Салакая - кандидат в вице-президенты). Заметим, что почти все эти кандидаты (кроме Какалия и Артура Анкваба) - выходцы из власти периода правления Рауля Хаджимбы, которые по тем или иным причинам ее покинули. Общее же у всех у них - стремление играть роль «третьей силы», которую олицетворяли и тандем Аршба - Барциц, и Астамур Тарба, и «Общее дело».

В принципе какие-либо электоральные перспективы из этих лиц имели лишь двое - Леонид Дзапшба и Шамиль Адзынба. Однако им мешали два обстоятельства. Во-первых, большое число кандидатов вообще и претендентов на роль «третьей силы» в частности. Во-вторых, по мнению аналитиков, «их потенциальный электоральный ресурс может быть значительно больше фактического. То есть в обществе есть сторонники во всяком случае Адзынба и Дзапшба, но сильны установки на то, что «они и так не пройдут, поэтому будем голосовать за...»

Таким образом, к началу выборной кампании были созданы все условия для фрагментации как провластного, так и оппозиционного электората.

\footnotetext{
5 «Амцахара» выдвинула на пост президента не Бжания, а Квициниа // EADaily. - 2019. - 10 июля. - URL: https://eadaily. com/ru/news/2019/07/10/amcahara-vydvinula-na-post-prezidenta-abhazii-ne-bzhaniya-a-kviciniya

${ }^{6}$ Алхас Квициниа: ничьи интересы я никогда не обслуживал и обслуживать не собираюсь // Апсадгьыл-инфо. - 2019. - 10 июля. - URL: https://apsadgil.info/news/politics/alkhas-kvitsiniya-nichi-interesy-ya-nikogda-ne-obsluzhival-i-obsluzhivatne-sobirayus/

7 Был снят с предвыборной гонки 20 августа, так как не успел вовремя подать в ЦИК кандидатуру вице-президента вместо снявшего свою кандидатуру Давида Дасания.

8 Кривенюк A. «Честно, но без конкретики» - в Абхазии завершилась президентская кампания // EADaily. - 2019. 23 августа. - URL: https://eadaily.com/ru/news/2019/08/23/chestno-no-bez-konkretiki-v-abhazii-zavershilas-prezidentskayakampaniya
} 


\section{НА ПУТИ К ПЕРВОМУ ТУРУ}

Предвыборная кампания прошла относительно спокойно. Позиции основных сторон имели к ее началу следующие параметры. Власть получила определенные тактические преимущества, в результате того что оппозиция вынуждена была срочно искать кандидата-дублера и его «раскручивать».

Важно отметить, что Рауль Хаджимба начал активную предвыборную кампанию в виде встреч с избирателями приблизительно 12 августа. Именно на период предвыборной агитации пришелся ряд решений правительства о социальных выплатах отдельным группам населения, об изменении таможенных пошлин на орех-фундук, решение о предстоящем открытии сухумского аэропорта. Сюда же стоит отнести многочисленные ремонты дорог, проведение освещения и т. д. Такое совпадение оппозиция сочла использованием административного ресурса и формой подкупа избирателей. О чем сделали соответствующие заявления партия «Амцахара» ${ }^{9}$ и штаб Квициниа ${ }^{10}$.

Рауль Хаджимба отказался от участия в дебатах кандидатов перед первым туром 23 августа. Этот факт также вызвал у Квициниа негативную реакцию. С ним солидаризировались Артур Анкваб и Шамиль Адзынба ${ }^{11}$.

Оппозиция же после выдвижения Алхаса Квициниа начала кампанию, что называется, с низкого старта. 1 августа была презентована его предвыборная программа. Она представляла собой масштабный анализ сложившейся в стране ситуации, содержала конкретные планы реформирования государственного управления, политической системы, экономики ${ }^{12}$. Наличие программы не могло не стать важным козырем в руках оппозиции. Ведь еще перед началом избирательной кампании аналитики указывали, что «первое общее впечатление - крайняя интеллектуальная бедность кандидатов» ${ }^{13}$. При всей резкости этой оценки приходится признать, что для нее имелись определенные основания. Презентация программы Квициниа выделила этого кандидата из общего ряда. Кроме того, с самого начала - с первых чисел августа - он активно встречался с избирателями (по две встречи в день).

В качестве особой черты кампании Квициниа следует указать на то, что он получил поддержку такой фигуры, как Сонер Гогуа, президент Международного фонда «Апсны». Поддержка Гогуа позволила ему работать с такими электоральными группами, как абхазская диаспора в Турции ${ }^{14}$ и репатрианты в самой Абхазии.

Рассматривая кампании Хаджимбы и Квициниа, стоит отдельно выделить такую тему, как их позиционирование по отношению к неабхазским этническим общинам (армянской, русской, мингрельской, греческой). Этот вопрос интересен под двумя углами зрения. Во-первых, победа на выборах президента для любого кандидата всегда связана с возможностью выхода за собственно абхазское этническое поле, добора голосов за его пределами. В ходе нынешней избирательной кампании можно было наблюдать усилия и Хаджимбы, и Квициниа по привлечению на свою сторону армянского электората. Во-вторых, потому что тема межэтнических отношений стала одной из полемических (пусть и неявно акцентируемых) для власти и оппозиции.

В своем выступлении на съезде ФНЕА 24 июля Рауль Хаджимба заявил, что будет опираться

\footnotetext{
9 «Амцахара»: не допустим той ситуации, которая сложилась во время президентских выборов 2014 года // Апсадгьылинфо. - 2019. - 17 августа. - URL: https://apsadgil.info/news/politics/amtsakhara-ne-dopustim-toy-situatsii-kotoraya-slozhilasvo-vremya-prezidentskikh-vyborov-2014-goda/

10 Штаб кандидата в президенты Квициниа: кандидат в президенты Рауль Хаджимба использует государственный peсурс // Апсаыгьыл-инфо. - 2019. - 18 августа. - URL: https://apsadgil.info/news/politics/shtab-kandidata-v-prezidentykvitsinia-kandidat-v-prezidenty-raul-khadzhimba-ispolzuet-gosudartvenny/

11 Алхас Квициниа: своим неучастием в теледебатах президент продемонстрировал пренебрежение к своему народу // Апсадгьыл-инфо. - 2019. - 23 августа. - URL: https://apsadgil.info/news/politics/alkhas-kvitsinia-svoim-neuchastiem-vteledebatakh-prezident-prodemonstriroval-prenebrezhenie-k-svoem/

${ }^{12}$ Алхас Квициниа: «Республика Абхазия - это государство, которое принадлежит всем нашим гражданам» // Абхазияинформ. - 2019. - 1 августа. - URL: http://abkhazinform.com/tochka-zreniya/item/9151-alkhas-kvitsinia-respublika-abkhaziyaeto-gosudarstvo-kotoroe-prinadlezhit-vsem-nashim-grazhdanam

${ }^{13}$ Кривенюк A. «Богатство выбора»: как нащупать логику голосования на президентских выборах в Абхазии // ЕАDаily. - 2019. - 7 июля. - URL: https://eadaily.com/ru/news/2019/07/07/bogatstvo-vybora-kak-nashchupat-logiku-golosovaniya-navyborah-v-abhazii

${ }^{14}$ Отметим, что в итоге на выборах турецкая диаспора в голосовании участия не приняла. ЦИК не открыл избирательный участок в Стамбуле. Оппозиция обвинила власти в том, что они лишили диаспору права голоса.
} 
«на знания, опыт и поддержку всего нашего народа: абхазов, русских, армян, представителей других национальностей» ${ }^{15}$.

Выступая 1 августа с программной речью, Алхас Квициниа затронул ту же тему под несколько иным углом: «Если раньше, в период вооружённого конфликта и существования непосредственной угрозы его возобновления, тяжёлое положение дел разделяли все национальности, проживающие в Абхазии, видевшие в абхазах настоящих защитников, то теперь ситуация, к сожалению, меняется. Если подобная тенденция сохранится, то значительная часть населения страны уже не будет заинтересована в сохранении нашей государственности, которая не предоставляет им в должной мере возможности для развития. Чтобы избежать этой опасности, необходимо обеспечить большее участие представителей разных национальностей во всех ветвях власти...» ${ }^{16}$.

Такая полемика явно не случайна. Начнем с того, что между властью и оппозицией все время президентства Хаджимбы шла полемика о законности и политической целесообразности лишения абхазского гражданства гальских мингрелов. Кроме того, проведенный в период Хаджимбы обмен паспортов привел к крупному скандалу, когда парламенту пришлось вносить коррективы в законодательство о гражданстве. Дело в том, что согласно закону, гражданами признаются лица, жившие в Абхазии в течение пяти лет до 12 октября 1999 г. При этом собственно абхазы могут легко обойти данную норму, так как они имеют право на гражданство автоматически. В результате органы МВД при обмене паспортов стали требовать у неабхазов подтверждения их жительства в указанный период. Возникла угроза потери гражданства у части граждан. Это дало некоторым экспертам повод говорить о возможности появления в стране жестких межэтнических антагонизмов ${ }^{17}$.

Цитированный пассаж из речи Квициниа свидетельствует о его обеспокоенности тем, что ситуация нарушения межэтнического мира может обернуться во вред абхазской государственности.

Тандем Олег Аршба - Олег Барциц вел достаточно активную кампанию. Основная ее форма - встречи с избирателями (как и Квициниа, по две в день), в которых всегда принимал участие Александр Анкваб. При этом Аршба и Барциц были единственной кандидатской парой, которая посетила Москву и встретилась с московской абхазской диаспорой (что выглядит логично в свете занимаемого Барцицем поста). Напомним, что в ходе выборов 2014 г. с московскими абхазами встретились все четыре кандида.

Позицию тандема Аршба - Барциц можно описать примерно так: они являлись оппонентами власти и конкурентами оппозиции. Такое позиционирование породило множество распространяемых в соцсетях слухов о возможном негласном договоре между Раулем Хаджимбой и Александром Анквабом. 5 августа в ходе встречи в селе Члоу Очамчырского района Анкваб сделал специальное заявление, в котором опроверг эти слухи ${ }^{18}$.

Важным событием кампании Аршбы было его поведение в ходе дебатов 23 августа, когда он покинул их, заметив отсутствие Хаджимбы. В своем заявлении он мотивировал свой поступок тем, что «отсутствие на эфире действующего президента лишало возможности участвовать с ним в открытом диалоге и опровергнуть распространяемые нашими оппонентами слухи о якобы существующем сговоре между нашей командой и Р. Хаджимба» ${ }^{19}$.

Избирательная кампания Астамура Тарбы прошла достаточно спокойно, без помпы. По своей интенсивности она уступала кампаниям Квициниа и Аршбы. Примерно то же самое можно сказать о кампании Леонида Дзапшбы. Однако стоит отметить, что в ходе кампании он зафиксировал свое неприятие как Рауля Хаджимбы, так и Александра Анкваба.

\footnotetext{
${ }_{15}^{15}$ Рауль Хаджимба: я буду опираться на знание и опыт поддержку всего народа Абхазии // Апсныпресс. $-2019 .-24$ июля. - URL: http://apsnypress.info/news/raul-khadzhimba-ya-budu-opiratsya-na-znaniya-opyt-i-podderzhku-vsego-naroda-abkhazii/

${ }^{16}$ Алхас Квициниа: «Республика Абхазия - это государство, которое принадлежит всем нашим гражданам» // Абхазияинформ. - 2019. - 1 августа. - URL: http://abkhazinform.com/tochka-zreniya/item/9151-alkhas-kvitsinia-respublika-abkhaziyaeto-gosudarstvo-kotoroe-prinadlezhit-vsem-nashim-grazhdanam

${ }^{17}$ Антон Кривенюк: Абхазия скатывается к времени межэтнических антагонизмов // EADaily. - 2918. - 28 июня. - URL: https://eadaily.com/ru/news/2018/06/28/anton-krivenyuk-abhaziya-skatyvaetsya-k-vremeni-mezhetnicheskih-antagonizmov

${ }^{18}$ Александр Анкваб: междумной и Хаджимбанет никакихдоговоренностей // Апсадгьыл-инфо. - 2019. - 5августа. - URL: https://apsadgil.info/news/politics/aleksandr-ankvab-mezhdu-mnoy-i-khadzhimba-net-nikakikh-dogovorennostey/?sphrase $\mathrm{id}=554$

${ }^{19}$ Олег Аршба объяснил причины своего неучастия в теледебатах кандидатов в президенты // Абхазия-информ. - 2019. - 24 августа. - URL: http://abkhazinform.com/item/9253-oleg-arshba-ob-yasnil-prichiny-svoego-neuchastiya-v-teledebatakhkandidatov-v-prezidenty
} 
Алмас Джапуа сделал упор на двух темах: расследовании деятельности «Черноморэнерго» и добычи нефти в Абхазии. Фактически он пытался с помощью двух этих тем обвинить окружение как Рауля Хаджимбы, так и Александра Анкваба в наличии у них общих интересов. 16 августа Джапуа собрал в офисе «Общего дела» пресс-конференцию, в ходе которой заявил, что в действиях РУП «Черноморэнерго» имеется коррупционная составляющая, в том числе имеет место торговля вырабатываемой на ИнгурГЭС энергии в Грузии и Турции ${ }^{20}$. Кроме того, он обвинил руководство «Черноморэнерго» в непрозрачных отношениях с грузинской стороной: якобы в состав правления грузинского ООО «ИнгуриГЭС» входят граждане Абхазии. Эти утверждения вызвали ответную реакцию главы «Черноморэнерго» Аслана Басария ${ }^{21}$.

Совершенно очевидно, что, обвиняя «Черноморэнерго» в непрозрачных отношениях с грузинской стороной и незаконной коммерческой деятельности, Джапуа целил в двух его руководителей - бывшего Резо Зантария и нынешнего Аслана Басария. При этом руководивший компанией в 2005-2014 гг. Зантария обвинялся сторонниками Рауля Хаджимбы в том, что он - человек Александра Анкваба. Что же касается Аслана Басария, то до 2014 г. Джапуа был его соратником: они вместе создавали фонд экспертного содействия «Айнар» (в 2015 г. преобразован в политическую партию).

Джапуа является стойким противником разработки нефти. При этом активным сторонником ее разведки и добычи является Александр Анкваб. Об этом он говорил, в том числе, в ходе нынешней предвыборной кампании ${ }^{22}$.

Еще до ее начала - в феврале 2019 г. - Джапуа обвинял компанию «Апсны-ойл» (имеет лицензию на геологоразведку в селе Окум Ткуарчальского района) в том, что она оформлена на подставное лицо ${ }^{23}$. До 2017 г. директором этой фирмы была Кристина Озган ${ }^{24}$ (в 2011-2014 гг. - заместитель руководителя АП РА). Кроме того, Джапуа называл Александра Анкваба предполагаемым бенефициаром сделки с «Апсны-ойл». Якобы в результате проведенной инспекции в районе села Окум Джапуа и его коллеги обнаружили, что на участке «Апсны-ойл» работает не эта фирма, а гудаутское ДРСУ-1, которое принадлежит бизнесмену Левану Тужбе - другу Анкваба ${ }^{25}$. В ответ на это близкий соратник Анкваба Леонид Лакербая написал большую статью об истории нефтеразведки в Абхазии ${ }^{26}$.

Шамиль Адзынба фактически стал не только кандидатом, но и лидером группы кандидатов Артур Анкваб, Астамур Какалия, Астамур Отырба (до снятия), - которые координировали свои действия и проводили совместные встречи. Очевидно, что возможность выхода во второй тур или просто получение солидного пакета голосов имел только Адзынба. Более того, российские телеграм-каналы в последние дни перед первым туром стали регулярно публиковать опросы, согласно которым Адзынба был фаворитом гонки и гарантированно выходил во второй тур. Как показали результаты первого тура, данные опросов были завышены. Однако если бы количество кандидатов было меньшим, то шансы получения Адзынбой солидного пакета голосов были высоки.

При этом позиционирование данной группы кандидатов по вопросу о втором туре в случае невыхода кого-то из них было простым: «Мы поддержим любого, кроме действующего президента и экс-президента». Аналогичную позицию занял и Джапуа ${ }^{27}$.

В целом следует признать, что наличие сразу двух оппозиционных кандидатов и нескольких претендентов на роль «третьей силы» привело к тому, что протестный электорат оказался расколотым между несколькими кандидатами.

\footnotetext{
20 Шария В. «Информационная бомба» в офисе «Общего дела» // Эхо Кавказа. - 2019. - 16 августа. URL: https://www.ekhokavkaza.com/a/30113871.html

${ }^{21}$ Аслан Басария: «Среди учредителей ООО “ИнгуриГЭС” нет граждан Абхазии // Абхазия-информ. - 2019. - 19 августа. - URL: http://abkhazinform.com/item/9235-aslan-basariya-sredi-uchreditelej-i-soveta-direktorov-ooo-inguriges-grazhdanabkhazii-net

22 Шария B. Качать или не качать: предвыборные дебаты о нефти // Эхо Кавказа. - 2019. - 9 августа. URL: https://www.ekhokavkaza.com/a/30102113.html

23 Заводская Е. Фирмы-матрешки и нефтяное лобби // Эхо Кавказа. - 2019. - 6 февраля. - URL: https://www.ekhokavkaza. com/a/29755266.html

24 Там же.

25 Заводская E. Александр Анкваб: я - достаточно информированный человек // Эхо Кавказа. - 2019. URL: https://www.ekhokavkaza.com/a/29777177.html

26 Шария В. «Белые пятна» в истории поиска «черного золота» в Абхазии // Эхо Кавказа. - 2019. - 22 марта. URL: https://www.ekhokavkaza.com/a/29836951.html

27 Шария B. Трое кандидатов встретились с учеными и писателями //Эхо Кавказа. - 2019. - 15 августа. URL: https://www.ekhokavkaza.com/a/30111760.html
} 


\section{ПЕРВЫЙ ТУР И ЕГО ПОСАЕАСТВИЯ}

25 августа при явке в 65,61 \% голоса распределись следующим образом:

Рауль Хаджимба - 20551 голос $(24,83 \%)$;

Алхас Квициниа - 18955 голосов $(22,91 \%)$;

Олег Аршба - 18668 голосов $(22,56 \%)$;

Астамур Тарба - 5703 голоса (6,89\%);

Леонид Дзапшба - 4938 голосов $(5,97 \%)$;

Шамиль Адзынба - 3579 голосов $(4,32 \%)$;

Алмас Джапуа - 1755 голосов (2,12\%);

Артур Анкваб - 1403 голоса $(1,7 \%)$;

Астамур Какалия - 841 голос $(1,02 \%)$.

Против всех проголосовали 1666 избирателей. Недействительных бюллетеней было $4693^{28}$.

Как уже было сказано выше, возникла ситуация трех лидеров с минимальным разрывом. И наиболее острая борьба развернулась между двумя оппозиционными кандидатами. Кто из них вышел во второй тур, выяснилось лишь под утро 26 августа.

Таким образом, оба претендента на пост главы государства - Рауль Хаджимба и Алхас Квициниа - оказались в ситуации необходимости срочного расширения собственного электората. И сразу же многие эксперты (например, известный журналист и аналитик Инал Хашиг) сделали вывод, что «во втором туре победит тот кандидат, который сумеет договориться с Александром Анкваб» ${ }^{29}$. В этой логике получается, что если Анкваб как политический наставник команды Аршба договаривается с кем-то из участников второго тура, то его электорат переходит к этому участнику договора.

На следующий день - 26 августа - прошла встреча Рауля Хаджимбы и Александра Анкваба, в ходе которой экс-президенту был предложен пост премьер-министра. Сначала об этом говорили в соцсетях. 4 сентября в ходе встречи с активом избирательных штабов Аршбы эту информацию подтвердил Леонид Лакербая. На этой встрече Лакербая заявил, что не может голосовать за Хаджимбу, но не может «поддержать и кандидатуру, которую поддерживает ОНД, оказавшееся сильнее партии ветеранов “Амцахара”». Он обвинил в срыве договоренностей между командой Аршбы и «Амцахара» Сергея Шамбу, Батала Табагуа и Беслана Эшбу ${ }^{30}$.

При этом большинство активистов высказались за то, чтобы проголосовать против всех во втором туре ${ }^{31}$. В случае реализации такого сценария возникала реальная угроза срыва второго тура.

На следующий день - 5 сентября - «Амцахара» опровергла заявление Лакербая ${ }^{32}$. В тот же день в открытом письме к Лакербая Беслан Эшба заявил, что «на последних переговорах 03.09.2019 г., когда со стороны вашей команды поступило предложение возглавить Правительство Абхазии Александром Анкваб в случае победы нашего кандидата во втором туре, депутатом Парламента Абхазии Юрием Хагуш было сказано, что по возвращению в строй, после покушения на жизнь путём тяжелого отравления Аслана Бжания, нами, практически на всех встречах с избирателями, озвучено, что он займёт пост премьер-министра, и как быть с этим, на что Александр Золотинскович ответил, что он на это смотрит положительно. Думаю, вы понимаете, в каком положении мы оказываемся в таком случае. Ситуация говорит сама за себя» $»^{33}$

\footnotetext{
${ }_{28}$ Повторное голосование по выборам президента Абхазии состоится 8 сентября // Абха-зия-информ. - 2019. - 27 августа. - URL: http://abkhazinform.com/item/9271-povtornoe-golosovanie-po-vyboram-prezidenta-abkhazii-sostoitsya-8-sentyabrya

${ }^{29}$ Рокс Ю. Абхазию возглавит тот, кого поддержит Александр Анкваб // Независимая газета. - 2019. - 27 августа.

${ }^{30}$ Сторонники Аршба, Барциц и Анкваба настроены 8 сентября голосовать против всех // Абхазия-информ. - 2019. 4 сентября. - URL: http://abkhazinform.com/item/9297-storonniki-arshba-bartsits-i-ankvaba-nastroeny-8-sentyabrya-golosovatprotiv-vsekh

${ }^{31}$ Там же.

32 Партия «Амцахара»: «Мы должны быть едины в своем стремлении положить конец правления Хаджимба» // Абхазияинформ. - 2019. - 5 сентября. - URL: http://abkhazinform.com/tochka-zreniya/item/9298-partiya-amtsakhara-my-dolzhnybyt-ediny-v-svoem-stremlenii-polozhit-konets-pravleniyu-khadzhimba?fbclid=IwAR1s4VNWejgM7MWmSZ-yEJ7BC7p4iOgdFMrOBc8CVTxAxp05NMHVzOQ2HV0

${ }_{33}$ Беслан Эшба Леониду Лакербая: все происходящее никак не отражается на моем личном отношении к вам и к Александру Золотинсковичу // Апсадгьыл-инфо. - 2019. - 5 сентября. - URL: https://apsadgil.info/news/politics/beslan-eshba-leonidu-lakerbaya-vse-proiskhodyashchee-nikak-ne-otrazhaetsya-na-moem-lichnom-otnosheni/
} 
Однако вечером того же дня Алхас Квициниа заявил о достижении с Александром Анквабом договоренности о поддержке по всем вопросам во втором туре ${ }^{34}$. В этой ситуации почти все комментаторы стали предрекать почти автоматическую победу Алхасу Квициниа.

\section{ВТОРОЙ ТУР И ПОСАЕ НЕГО}

Однако в результате второго тура голоса распределились следующим образом:

Алхас Квициниа получил 38766 голосов, или 46,17 \%;

Рауль Хаджимба - 39793 голоса, или 47,39\%;

Против всех было подано 3155 голосов.

Явка составила 65,99\% (83963 от списочного состава в 127232 избирателей $)^{35}$.

Такие итоги следует рассмотреть с двух точек зрения - электорально-математической и политической.

С первой точки зрения такие показатели свидетельствуют, что сторонники Алхаса Квициниа сумели с помощью своего соглашения с Александром Анквабом (если считать чисто арифметически) добрать большое количество голосов. Однако и власть сумела мобилизовать значительную часть электората.

Отдельно стоит порассуждать о том, как именно власть мобилизовала электорат в свою поддержку. Оппозиция обвиняет власть в многочисленных нарушениях и подкупе избирателей, но до сих пор не предъявила существенного пакета данных, которые бы убедительно свидетельствовали об этом.

В отсутствие у нас четкой социологии можно сделать несколько предположений. В частности, не исключено, что на сторону Рауля Хаджимбы склонился электорат многочисленных претендентов на роль «третьей силы» (Астамура Тарбы, Леонида Дзяпшбы, Шамиля Адзынбы и др.). Такой версии придерживается сторонник «третьей силы», бывший депутат парламента Ахра Бжания ${ }^{36}$. Голосование за Хаджимбу в Сухумском и Гулрыпшском районах, где компактно проживает армянское население, говорит, что команда действующего президента сумела грамотно поработать и с национальными общинами.

Если же смотреть на цифры с политической точки зрения, то, безусловно, имеет место раскол общества на две почти равные части с минимальным (в несколько сот голосов) перевесом в пользу власти. А если сложить голоса за Квициниа и «против всех», то получается, что доля тех, кто не одобряют действуюшую власть даже больше, чем проголосовавших за Рауля Хаджимбу.

В этой ситуации были возможны два сценария. Первый - силовое противостояние по аналогии с имевшим место на выборах 2004 г. Второй - коалиция между бывшими соперниками, по образцу все той же коалиции между Сергеем Багапшем и Раулем Хаджимбой. Именно к такому сценарию призывали как влиятельные аналитики (Инал Хашиг ${ }^{37}$ ), так и группа общественных деятелей (Арда Инал-ипа, Лиана Кварчелия и др. ${ }^{38}$ ). Отметим, что последнюю инициативу поддержал и многолетний соратник Рауля Хаджимбы, глава АП в 2014-2016 гг. Астамур Тания.

Оппозиция не стала реализовывать силовой сценарий, ограничившись иском в Верховный суд о признании выборов недействительными, так как сумма голосов за Квициниа и против всех больше, чем сумма голосов за Хаджимбу. Этот иск оппозиция проиграла. Хотя она считает возможным выиграть апелляцию и кассацию в Верховном суде.

Что же касается возможности компромисса и сосуществования бывших оппонентов, то, по словам главы «Амцахары» Алхаса Квициниа, в ходе их встречи с Раулем Хаджимбой президент предложил ему пост вице-премьера. Квициниа отверг этот вариант, предложив в свою очередь

\footnotetext{
${ }^{34}$ Алхас Квициниа: мы договорились с Александром Анкваб // Апсадгьыл-инфо. - 2019. - 5 сентября. - URL: https:// apsadgil.info/news/politics/alkhas-kvitsinia-my-dogovorilis-s-aleksandrom-ankvab/

${ }^{35}$ Центризбирком опубликовал окончательные итоги выборов президента // Абхазия-информ. - 2019. - 9 сентября. URL: http://abkhazinform.com/item/9317-tsentrizbirkom-opublikoval-okonchatelnye-itogi-vyborov-prezidenta-abkhazii

${ }^{36}$ Бжания, Ахра. После выборов // Чегемская правда. - 2019. - 27 октября. - URL: https://www.chegem.su/politika/item/114posle-vyborov

${ }^{37}$ Хашиг И. В поисках компромисса // Чегемская правда. - 2019. - 11 сентября. - URL: https://www.chegem.su/politika/ item/82-v-poiskakh-kompromissa

38 Гражданские активисты предлагают Хаджимба и Квициниа подписать меморандум о мерах по преодолению внутриполитического кризиса в Абхазии // Абхазия-информ. - 2019. - 18 сентября. - URL: http://abkhazinform.com/ item/9358-grazhdanskie-aktivisty-predlagayut-khadzhimba-i-kvitsinia-podpisat-memorandum-o-merakh-po-preodoleniyuvnutripoliticheskogo-krizisa-v-abkhazii
} 
главе государства рассмотреть вопрос о назначении премьером Аслана Бжания, что отверг уже глава государства ${ }^{39}$.

Таким образом, президентские выборы породили новую - уникальную - политическую ситуацию в Абхазии.

\section{ЗАКАЮЧЕНИЕ}

Эту ситуацию можно оценить как политический пат. Оппозиция демонстративно не пошла на силовой сценарий, а власть вынуждена будет существовать на фоне постоянных упреков в нелегитимности.

На уровне политической символики это ярко иллюстрируется тем, что 9 октября в один и тот же час прошли инаугурация Рауля Хаджимбы и собрание актива оппозиции, на котором было заявлено о фактическом непризнании его президентом.

Возникает вопрос: что дальше?

Если не произойдет чего-то форс-мажорного (решения Верховного суда в пользу оппозиции или даже некоего силового эксцесса), то ближайшая дата, которую стоит рассматривать - это март 2022 г., когда пройдут очередные парламентские выборы. Многое зависит от того, сумеет ли оппозиция переформатироваться и подготовиться к ним.

12 октября стало известно, что Аслан Бжания вернулся после лечения в Москву для дальнейшей реабилитации, после которой намерен в выехать в Абхазию. Если это произойдет, то у оппозиции вновь появится признанный и сильный лидер. Многое будет зависеть и от того, насколько успешен будет этот курс реабилитации. Если Бжания сумеет вернуться к полноценной политической деятельности, не исключено, что оппозиция получит «второе дыхание».

Переформатирование неизбежно и в провластном лагере. Нынешний президентский срок Рауля Хаджимбы - последний. В 2024 г. он должен выдвинуть преемника. Очевидно, что «раскрутка» такого преемника должна начаться не позднее 2022 г. Что совпадает по времени с парламентскими выборами.

Но развитие политической ситуации будет зависеть не только от борьбы власти и оппозиции. Многое обусловлено социально-экономическими факторами. Некоторые обстоятельства указывают на то, что уже в ближайшие месяцы стабильность в Абхазии может пошатнуться.

В феврале-мае 2020 г. будет поставлена на ремонт ИнгурГЭС. В 2016 г. Абхазия уже испытала последствия остановки станции на три недели. Ценой - в прямом и переносном смысле - решения энергетической проблемы стали почти 0,5 млрд руб., которыми были оплачены поставки электроэнергии из России. Эти поставки производились по российским тарифам, которые в разы превосходят тарифы абхазские. Деньги были списаны в результате взаимозачетом из российской финансовой помощи. Примерная стоимость поставок электроэнергии после остановки ИнгурГЭС в 2020 г. - 3,5 млрд руб. То есть в полтора раза больше российской финансовой помощи Абхазии ${ }^{40}$. Как образно выразился Инал Хашиг, «...пережить последствия этой остановки ГЭС без осложнения внутриполитической ситуации в Абхазии не получится. Даже если к этому времени оппозиционная “Амцахара” не придет в себя - толпа злых и решительных граждан у президентского дворца соберется стихийно. И успокоить ее, отдав на откуп пару министерских портфелей, не получится» ${ }^{41}$.

Помимо энергетической проблемы, есть и другие потенциальные «спусковые крючки» возможной политической нестабильности. 4 ноября 2019 г. в интервью агентству «Абхазия-информ» председатель Национального банка РА Беслан Барателия заявил, что «из-за крайнего дефицита кредитных ресурсов с 1 июля 2019 г. кредитование в Сбербанке временно приостановлено. И, несмотря на многочисленные просьбы клиентов, сегодня даже под 48 \% годовых получить кредит невозможно. Связано это с тем, что основным источником кредитования для Сбербанка являются вклады населения, которые, к сожалению, не превышают 20-30 млн руб. в месяц, в то время как спрос на кредиты, несмотря на их дороговизну, составляют около

\footnotetext{
${ }^{39}$ Хаджимба Квициниа: допустим, новые выборы, тогда я же с тобой всё уже, появятся другие кандидаты // Апсыдгьылинфо. - 2019. - 20 сентября. - URL: https://apsadgil.info/news/politics/khadzhimba-kvitsinia-dopustim-novye-vybory-togdaya-zhe-s-toboy-vsye-uzhe-poyavyatsya-drugie-kandida/?sphrase_id=662

${ }^{40}$ Хашиг И. Что стоит и что не стоит делать новоизбранному президенту Абхазии // Чегемская правда. - 2019. - 20 октября. - URL: https://www.chegem.su/politika/item/104-mnenie-kogda-vykhoda-net-chto-stoit-i-chto-ne-stoit-delat-novoizbrannomuprezidentu-abkhazii

${ }^{41}$ Там же.
} 
100 млн руб. в месяц». Более того, «перед нами стоит выбор: продолжать привлекать у наших граждан вклады под высокие проценты, и как следствие, предоставлять кредиты по высоким процентным ставкам, либо, опустив ставку по вкладам и сделав ее непривлекательной для вкладчиков, лишить банк кредитных ресурсов и прекратить кредитование». Барателия указывает, что «микрокредитование - это социальный вопрос, основными получателями кредита являются пенсионеры и бюджетники с низкими доходами» ${ }^{42}$. В этой связи нельзя исключать того, что дефицит на рынке кредитования и высокие ставки по кредитам могут стать источником социальной и в перспективе политической напряженности. В такой ситуации многое будет зависеть от того, как правительственная команда сумеет эффективно построить свою работу.

14 октября Рауль Хаджимба переназначил на пост премьер-министра Валерия Бганбу.

28 октября президент подписал указ о реорганизации структуры Кабинета Министров. Вкратце ее суть состоит в следующем. Два министерства реорганизованы в госкомитеты: Министерство сельского хозяйства - в Государственный комитет по сельскому хозяйству; Министерство по курортам и туризму - в Государственный комитет по курортам и туризму. Министерство здравоохранения и Министерство труда, занятости и социального обеспечения слиты в Министерство здравоохранения и социального обеспечения, в состав которого вошли Пенсионный фонд, Фонд социального страхования и охраны труда, Фонд обязательного медицинского страхования, Государственный внебюджетный фонд инвалидов Отечественной войны народа Абхазии 1992-1993 гг., Дорожный фонд. В состав нового Госкомитета по делам молодежи и спорту вошли Госкомитет по молодежной политике и Госкомитет по физической культуре и спорту. Вновь созданное Государственное управление по энергетике, транспорту и связи включило в себя Государственное управление связи и массовых коммуникаций, Государственное управление по транспорту, Службу государственного надзора за деятельностью в области связи. Указом президента были переименованы три министерства: Министерство культуры и охраны историко-культурного наследия - в Министерство культуры; Министерство репатриации в Министерство демографии и репатриации; Министерство образования и науки - в Министерство просвещения.Тем же указом глава государства предписал оптимизировать общую численность структур, входящих в Кабинет министров, не менее чем на $15 \%$.

4 ноября премьер Валерий Бганба на пресс-конференции заявил, что сокращение штатов коснется примерно 375 человек из имеющихся 2700 госслужащих, что приведет к высвобождению примерно 30-40 млн руб. Часть этой суммы будет направлена на государственные нужды, часть - передана в зарплатный фонд ведомств. Реорганизация не коснется МВД и Минобороны. Кроме того, премьер указал на раздутость штатов МЧС, ГТК, карантинной службы и фонда репатриации 44.7 ноября Бганба подписал распоряжение об оптимизации штатов, возложив ответственность за контроль за его исполнением на минфин и аппарат кабмина ${ }^{45}$.

Безусловно, оптимизация штатов направлена на повышение эффективности работы государственного механизма. Однако в существующих абхазских условиях эта мера, наоборот, может стать причиной новых конфликтов. В качестве примера приведем состоявшуюся 28 октября рокировку Беслана Цвинария на Гурама Инапшбу в качестве главы ГТК. Утром в день отставки Цвинария на заседании кабмина вступил в спор с премьером Бганбой и и. о. министра финансов Джансухом Нанбой. Причиной стал подписанный Цвинария ведомственный приказ, в котором он самостоятельно, без ведома минфина, установил суммы окладов для своих сотрудников. Однако этот приказ в проекте государственного бюджета и. о. министра финансов не учтен. В этом последнего поддержал премьер, указавший на раздутые штаты таможни. В свою очередь Цвинария заявил, что не собирается отменять приказ, а «если вы снимаете меня, назначаете другого, то пускай новый руководитель отменяет приказ. Я посмотрю, как

\footnotetext{
42 Беслан Барателия: в сложившейся ситуации кредиты могут быть либо дорогими, либо их выдача будет невозможна // Абхазия-информ. - 2019. - 4 ноября. - URL: http://abkhazinform.com/item/9535-beslan-barateliya-v-slozhivshejsya-situatsiikredity-mogut-byt-libo-dorogimi-libo-ikh-vydacha-budet-nevozmozhna

${ }^{43}$ Президент изменил структуру Кабинета министров // Спутник-Абхазия. - 2019. - 28 ноября. - URL: https:/sputnikabkhazia.ru/Abkhazia/20191028/1028707687/Prezident-Abkhazii-izmenil-strukturu-Kabineta-ministrov.html

44 Валерий Бганба: новая структура кабмина предусматривает оптимизацию действующей системы органов государственной власти // Абхазия-информ. - 2019. - 4 ноября. - URL: http://abkhazinform.com/item/9534-valerij-bganbanovaya-struktura-kabmina-predusmatrivaet-optimizatsiyu-dejstvuyushchej-sistemy-organov-ispolnitelnoj-vlasti

45 Подписано распоряжение о проведении оптимизации штатов работников центральных органов власти // Абхазияинформ. - 2019. - 7 ноября. - URL: http://abkhazinform.com/item/9551-podpisano-rasporyazhenie-o-provedenii-optimizatsiishtatov-rabotnikov-tsentralnykh-organov-vlasti
} 
он отменит» ${ }^{46}$. Скорее всего, отставка Цвинария была решенным вопросом еще до заседания. Но тема раздутых штатов и должностных окладов, видимо, сыграла в ней не последнюю роль.

Современные социально-экономические реалии Абхазии дают немало поводов для политических кризисов. Нельзя исключать и того, что возможные перестановки в коридорах власти приведут к переходу в стан оппозиции политиков, ранее союзных Раулю Хаджимбе. В этой связи укажем на состоявшийся 21 октября уход в отставку мэра Сухума Адгура Харазия и назначение и. о. градоначальника Кана Кварчия. Хотя Харазия пока никак не проявил своих новых политических амбиций, обращает внимание, что причиной своей отставки он назвал слухи о том, что его хотят заменить ${ }^{47}$. Характерная деталь: Харазия отсутствовал на представлении и. о. мэра Кварчия коллективу городской администрации 22 октября ${ }^{48}$.

Не исключено и то, что в условиях «провисания» Хаджимбы и возможного кризиса оппозиции окажется успешной та самая «третья сила», которая не смогла сформироваться на выборах 2019 г. Каков будет формат такой «третьей силы» - вопрос отдельный. Своего рода кредо для нее почти сразу же после инаугурации Рауля Хаджимбы сформулировал бывший депутат парламента Ахра Бжания: «Сегодня очевидно, что действующие политические элиты не в состоянии решить стоящих перед страной задач. Что бы они не делали: объединялись, разъединялись, штурмовали друг друга, - ничего не получится. Они одинаковые. И там и там есть единый совковый подход к государству как к дойной корове, которую надо меньше кормить и больше доить. Абхазии, как свежий воздух, нужна новая политическая сила, новые лидеры, способные критически оценить состояние наших дел и выстроить план Действия. Через год они должны сформировать политическую повестку страны и держать власть в тонусе. Через два - избраться в Парламент, а через пять - выдвинуть своего кандидата на президентских выборах и победить» ${ }^{49}$.

Однако уже сейчас очевидно: абхазскую политику ждут перемены.

\title{
АИТЕРАТУРА
}

1. Муханов В. М. О текущем состоянии церковного раскола в Абхазии // Международная аналитика. - 2016. - № 1. - С. 129-137.

2. Новиков В. В. Абхазия в 2014-2017 гг. (Динамика внутриполитического кризиса) // Международная аналитика. - 2018. - № 1. - С. 101-110.

3. Новиков В. В. Абхазия - 2018: динамика внутриполитического процесса в перспективе президентских выборов // Международная аналитика. - 2019. - № 1-2. - С. 104-113.

\section{VLADIMIR NOVIKOV}

\section{ABKHAZIA - 2019: FROM KHAJIMBA TO KHAJIMBA}

\author{
Vladimir Novikov, PhD (History), senior researcher, \\ Institute for Social and Political Studies \\ of the Black Sea - Caspian Region. \\ E-mail: novik222@mail.ru
}

\begin{abstract}
Summary. The paper considers the course and outcomes of 2019 Presidential election campaign in Abkhazia as well as factors that stipulated its character (postponement of elections because of Aslan Bzhania's disease, the number of contenders, etc.). The alignment of forces before the campaign is outlined, and the principal contenders are characterized, together with political forces that promoted them. A due attention is paid to the extraordinary polycentrism of Abkhaz politics, in
\end{abstract}

\footnotetext{
${ }^{46}$ Шария В. Абхазским оппозиционерам выплатят почти миллион рублей // Эхо Кавказа. - 2019. - 28 октября. URL: https://www.ekhokavkaza.com/a/30240807.html

${ }^{47}$ Гилоян Э. Из-за слухов: мэр Сухума Адгур Харазия подал в отставку // Чегемская правда. - 2019. - 21 октября. URL: https://www.chegem.su/politika/item/105-iz-za-slukhov-mer-sukhuma-adgur-kharaziya-podal-v-otstavku

${ }^{48}$ Рауль Хаджимба: Сухум должен меняться! // Абхазия-информ. - 2019. - 22 октября. - URL: http://abkhazinform.com/ item/9474-raul-khadzhimba-sukhum-dolzhen-menyatsya

${ }^{49}$ Бжания, Ахра. После выборов // Чегемская правда. - 2019. - 27 октября. - URL: https://www.chegem.su/politika/item/114posle-vyborov
} 
which not only the authority, opposition and the "third force" but also various electoral competitors of both the authority and the opposition, as well as numerous contenders to the role of the "third force" co-exist. Such disposition led to scattering of the electorate at the presidential election. The course of the electoral campaign is scrutinized with an emphasis put on the analysis of programmatic provisions of the contenders and their political style. The political maneuvers of the authority, opposition and Alexander Ankvab' team between two rounds of the elections are traced. A special attention is paid to the causes of Raul Khajimba's victory. The situation after the elections is also considered in the paper, and a prognosis is suggested of possible development.

Keywords: Abkhazia, Raul Khajimba, Aslan Bzhania, Alkhas Kwitzitnia,Oleg Arshba, Aslan Bzhania, Sergey Shamba Alexander Ankvab.

\section{REFERENCES}

Mukhanov V. M. O tekushchem sostoyanii tserkovnogo raskola v Abkhazii [On the Current Status of the Church Schism in Abkhazia]. International Analytics. 2016. No. 1. P. 129-137.

Novikov V. V. Abkhazia v 2014-2017 (Dinamika vnutripoliticheskogo krizisa) [Abkhazia in 2014-2017 (The Internal Political Crisis Dynamics)]. International Analytics. 2018. No. 1. P. 101-110.

Novikov V. V. Abkhazia v 2018: Dinamika vnutripoliticheskogo processa v perspective prezidentskikh viborov [Abkhazia - 2018: the Dynamics of Domestic Political Process in the Prospect of Presidential Election]. International Analytics. 2019. No. 1-2. P. 104-113. 